\title{
Slow-growing amelanotic malignant melanoma of the esophagus with long survival: a case report and review of the literature
}

\section{(ㄷ) (i) $(-)$}

\author{
Authors \\ Yasuhiro Shimizu ${ }^{3}$, Yasushi Yatabe ${ }^{4}$, Yasumasa Niwa ${ }^{1}$ \\ Institutions \\ 1 Department of Endoscopy, Aichi Cancer Center \\ Hospital, Aichi, Japan \\ 2 Department of Gastroenterology, Aichi Cancer Center \\ Hospital, Aichi, Japan \\ 3 Department of Gastroenterological Surgery, Aichi \\ Cancer Center Hospital, Aichi, Japan \\ 4 Department of Pathology and Molecular Diagnosis, \\ Aichi Cancer Center Hospital, Aichi, Japan
}

Yutaka Hirayama ${ }^{1}$, Tajika Masahiro' ${ }^{1}$, Tsutomu Tanaka ${ }^{1}$, Makoto Ishihara ${ }^{1}$, Sachiyo Ohnishi ${ }^{1}$, Kazuo Hara ${ }^{2}$, Nobumasa Mizuno $^{2}$, Susumu Hijioka², Nozomi Okuno ${ }^{2}$, Tetsuya Abe $^{3}$, Norihisa Uemura ${ }^{3}$, Jiro Kawakami ${ }^{3}$, Shintarou Kurahashi ${ }^{3}$,

submitted 8.3.2017

accepted after revision 26.6.2017

\author{
Bibliography \\ DOI https://doi.org/10.1055/s-0043-117951 | \\ Endoscopy International Open 2017; 05: E1076-E1080 \\ (c) Georg Thieme Verlag KG Stuttgart · New York \\ ISSN 2364-3722
}

\author{
Corresponding author \\ Yutaka Hirayama, Department of Endoscopy, Aichi Cancer \\ Center Hospital, 1-1 Kanokoden, Chikusa-ku, Nagoya, Aichi \\ 464-8681, Japan \\ Fax: +81-52-764-2963 \\ yhirayama@aichi-cc.jp
}

\section{ABSTRACT}

Background and study aims We report a case of amelanotic malignant melanoma of the esophagus (AMME), an exceedingly rare disease. A 77-year-old Japanese woman presented to our hospital with features suggestive of a middle esophageal submucosal tumor, which was diagnosed pathologically as AMME. The patient underwent thoracoscopic resection of the esophagus and laparoscopic gastric tube reconstruction. Three years after surgery, computed tomography showed no recurrence. Generally, the prognosis of malignant melanoma of the esophagus is very poor. However, our patient had no recurrence, and is alive 3 years after surgery and 5 years after the tumor was first detected.

\section{Introduction}

Primary amelanotic malignant melanoma of the esophagus (PAMME) is an extremely rare disease with a poor prognosis, often progressing with multiple metastases even in the early stages of the disease; only a few case reports have been published in the literature. PAMME is frequently misdiagnosed at biopsy as poorly differentiated squamous cell carcinoma (SCC), sarcoma, spindle cell carcinoma, or undifferentiated carcinoma because of the negligible amounts of melanin pigments, which are characteristic of malignant melanoma, and the morphological features of the tumor cells. We herein report the case of a long-surviving patient with a slow-growing amelanotic malignant melanoma of the esophagus (AMME).

\section{Case Report}

A 77-year-old woman was admitted to our hospital in 2013 for investigation and treatment of a submucosal tumor (SMT) of the esophagus, measuring $>2 \mathrm{~cm}$ in diameter, which had been detected by upper gastrointestinal barium series.

Initially, she had been advised to visit another hospital for investigation of the esophageal SMT, which had been earlier detected by esophagogastroduodenoscopy (EGD). However, she did not undergo any examination because she was asymptomatic as of 2011. In 2013, 2 years later, she was advised to return to hospital for investigation of the esophageal SMT which now measured $>2 \mathrm{~cm}$ in diameter, and had been detected by barium series performed to investigate a history of mild dysphagia. She was subsequently referred to our hospital in November 2013. On physical examination, we found no pigmen- 

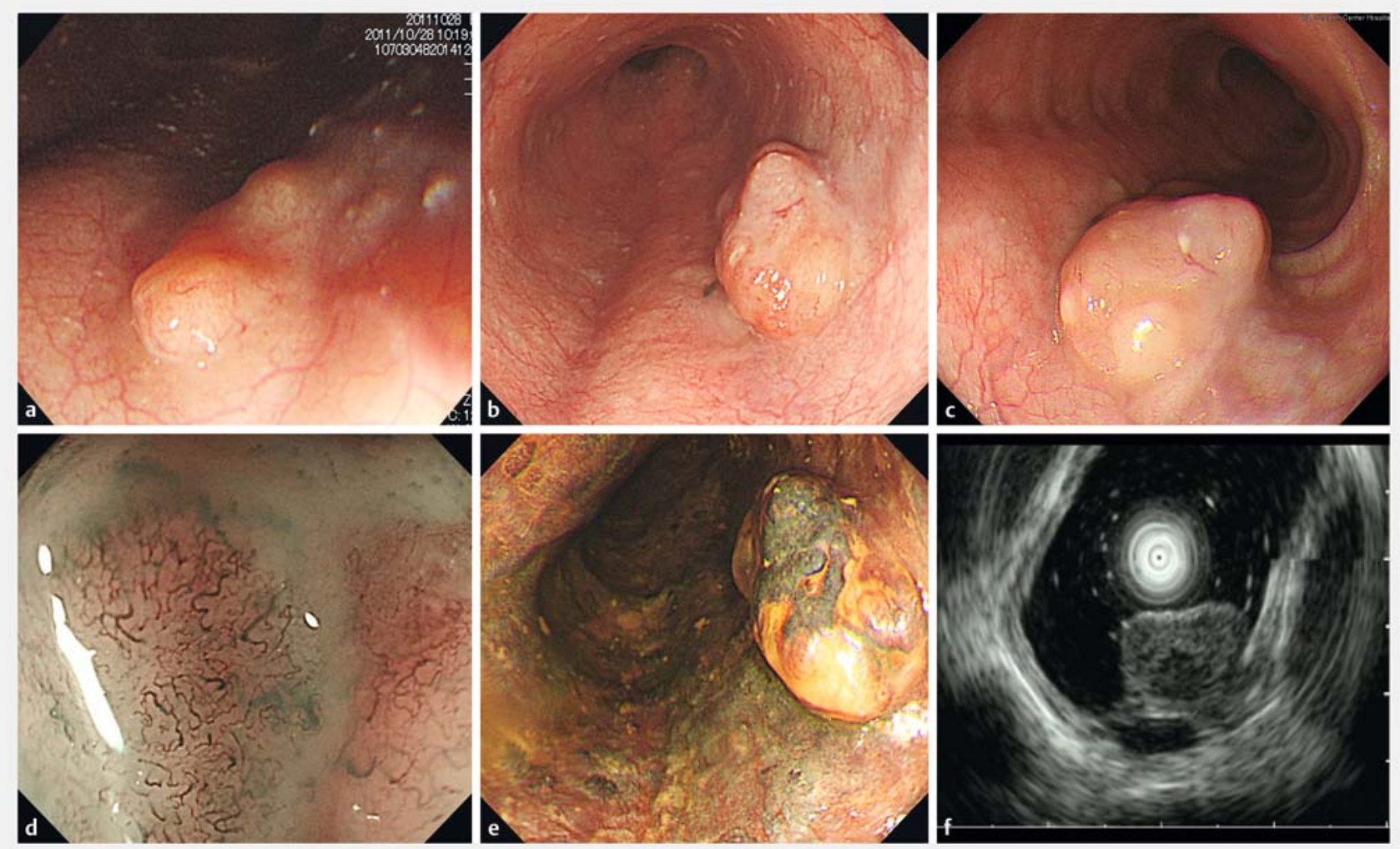

- Fig. 1 Endoscopic examination. a Esophageal SMT at first detection. b, c A well-defined non-pigmented elevated lesion with a flat proximal edge 2 years after first detection. $\mathbf{d}$ Narrow band imaging magnification endoscopy showing subepithelial structures resembling reticular vessels. e lodine staining. $\mathbf{f}$ Endoscopic ultrasonography depicted the tumor as a well-circumscribed low-echoic mass within the submucosal layer.

ted lesions in the eyes or skin, and no other abnormalities were detected. Results of blood tests were within normal limits.

On EGD ( $\triangleright$ Fig. 1), the lesion exhibited almost no change in size over the years. A well-defined non-pigmented elevated lesion with a flat proximal edge was situated $23 \mathrm{~cm}$ from the incisors, and extended to $25 \mathrm{~cm}$ from the incisor teeth. Magnifying endoscopy with narrow-band imaging showed subepithelial structures resembling reticular vessels. On the surface of the lesion, we could not identify features of intrapapillary capillary loop changes such as dilatation, meandering, change in caliber, variety in shape, and destruction, which are regarded as typical findings in esophageal SCC. The findings in the lesion seemed to be different from the typical findings of esophageal SCC. Endoscopic ultrasonography depicted the tumor as a well-circumscribed and low-echoic mass within the submucosal layer.

Histological examination of a biopsy specimen showed proliferation of malignant spindle cells. Minimal melanin pigment was seen on hematoxylin and eosin staining and the histology of the tumor was relatively uniform. Immunohistochemically, the tumor cells were positive for CD117, S-100 protein, MITF, and HMB 45, and negative for CD34, actin, and Dog1.Ki67-positive cells comprised $1-3 \%$. These findings confirmed the diagnosis of malignant melanoma of the esophagus (MME). Computed tomography and positron emission tomography - computed tomography showed no metastasis.

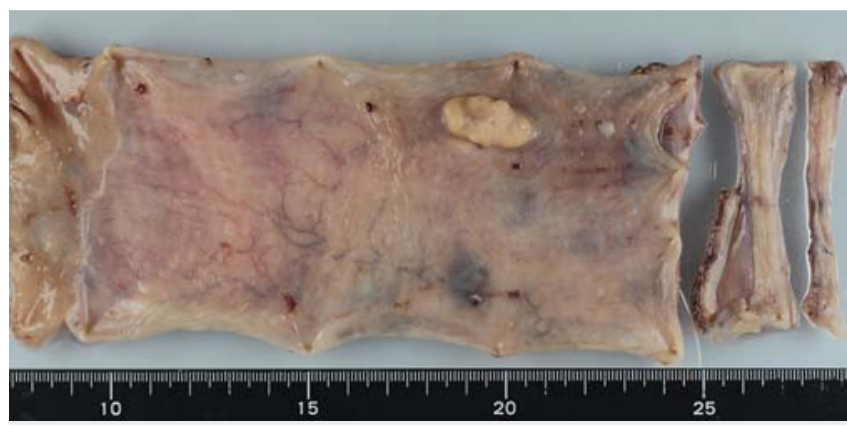

- Fig. 2 Resected specimen showing a $20 \times 12 \mathrm{~mm}$ non-pigmented elevated tumor.

Consequently, we made a definitive diagnosis of middle esophageal malignant melanoma without metastasis. Subsequently, the patient underwent thoracoscopic resection of the esophagus and laparoscopic gastric tube reconstruction, which was performed by pulling up the stomach via the retrosternal route; the anastomotic site was the neck.

The resected specimen contained an elevated and non-pigmented whitish tumor, measuring $20 \times 12 \mathrm{~mm}$ ( $\triangleright$ Fig. 2). The depth of tumor invasion was to the submucosal layer. The tumor was composed of epithelioid and polyhedral cells arranged in alveolar clusters. The nuclei were bizarre and hyperchromatic 

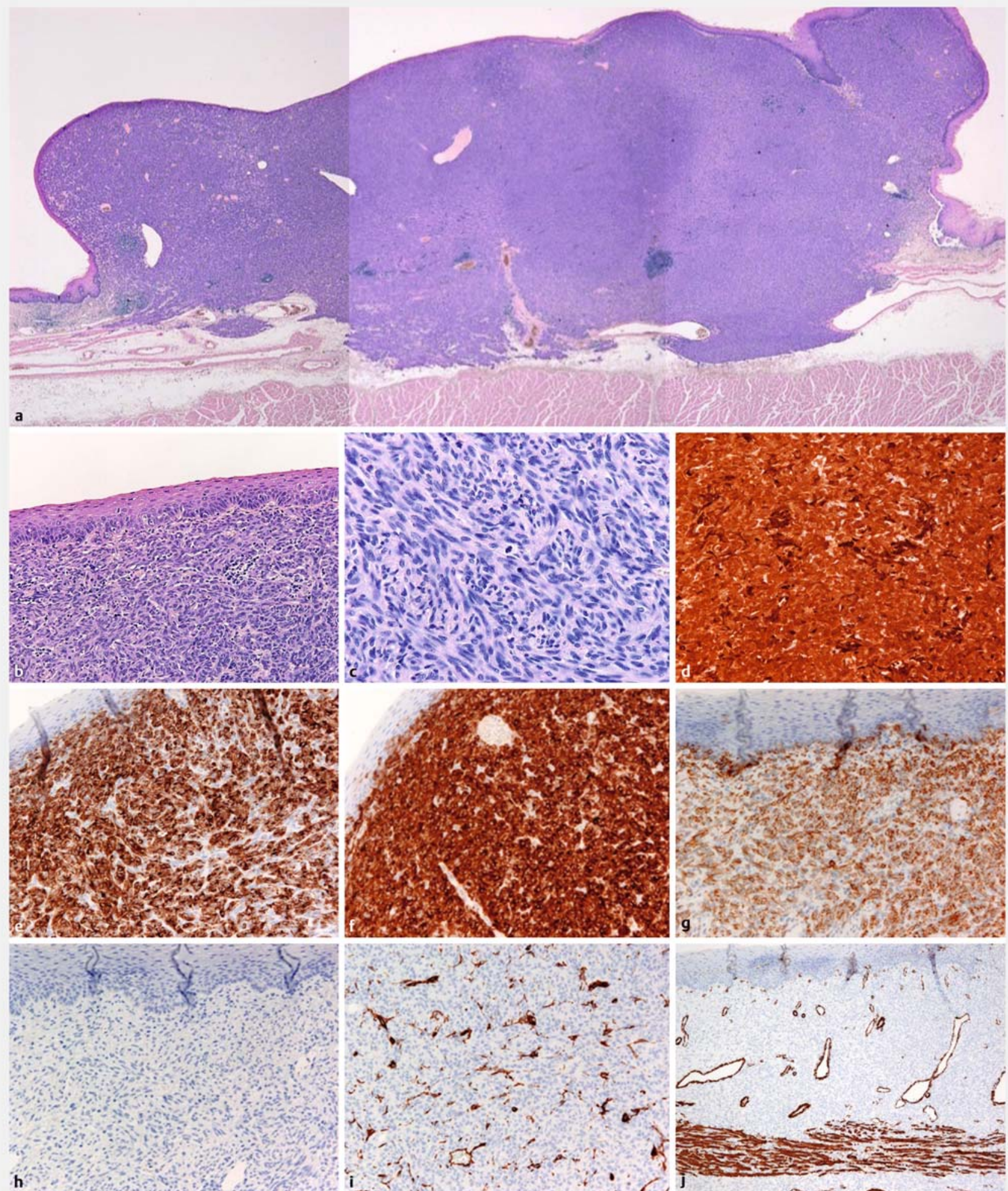

- Fig. 3 Histopathological findings. a, b, c Hematoxylin and eosin staining (macroscopic finding, $\times 200, \times 400$ ). d, e, f, $\mathbf{g}$ Tumor cells were positive for S-100 (×400), HMB-45 (×200), Melan-A (×200), and CD117 (×200). h, i, j Tumor cells were negative for Dog1 (×200), CD34 (×200), and actin $(\times 40)$. 
- Table 1 Search results for case reports of amelanotic malignant melanoma of the esophagus between 1996 and 2015.

\begin{tabular}{|c|c|c|c|c|c|c|c|}
\hline Reference & Age/sex & Chief complaint & $\begin{array}{l}\text { Endoscopic } \\
\text { findings }\end{array}$ & Location & Size & Treatment & Prognosis \\
\hline $\begin{array}{l}\text { Carr-Locke } \\
\text { et al. [9] }\end{array}$ & $66 /$ female & $\begin{array}{l}\text { Retrosternal chest } \\
\text { discomfort }\end{array}$ & $\begin{array}{l}\text { Polypoid and ul- } \\
\text { cerated tumor }\end{array}$ & $\begin{array}{l}\text { Distal } \\
\text { esophagus }\end{array}$ & $3.5 \mathrm{~cm}$ & Surgery & $\begin{array}{l}\text { n.a. } \\
\text { alive } 2 \text { months after } \\
\text { surgery }\end{array}$ \\
\hline $\begin{array}{l}\text { Lohmann } \\
\text { et al. [10] }\end{array}$ & $63 /$ male & Dysphagia & Sessile tumor & $\begin{array}{l}\text { Middle } \\
\text { esophagus }\end{array}$ & $3.6 \mathrm{~cm}$ & $\begin{array}{l}\text { Surgery and } \\
\text { CT }\end{array}$ & $\begin{array}{l}\text { Died } 12 \text { months } \\
\text { after diagnosis }\end{array}$ \\
\hline $\begin{array}{l}\text { Lohmann } \\
\text { et al. [10] }\end{array}$ & $67 /$ female & Dysphagia & $\begin{array}{l}\text { Polypoid and ul- } \\
\text { cerated tumor }\end{array}$ & $\begin{array}{l}\text { Middle } \\
\text { esophagus }\end{array}$ & $2.2 \mathrm{~cm}$ & Surgery & $\begin{array}{l}\text { Alive } 60 \text { months } \\
\text { after surgery }\end{array}$ \\
\hline $\begin{array}{l}\text { Lohmann } \\
\text { et al. [10] }\end{array}$ & $72 /$ male & Dysphagia & Polypoid tumor & $\begin{array}{l}\text { Middle } \\
\text { esophagus }\end{array}$ & n.a. & Laser ablation & $\begin{array}{l}\text { Died } 13 \text { months } \\
\text { after diagnosis }\end{array}$ \\
\hline $\begin{array}{l}\text { Lohmann } \\
\text { et al. [10] }\end{array}$ & 70/female & Anorexia & $\begin{array}{l}\text { Sessile and ulcer- } \\
\text { ated tumor }\end{array}$ & $\begin{array}{l}\text { Distal } \\
\text { esophagus }\end{array}$ & $10 \mathrm{~cm}$ & Surgery & $\begin{array}{l}\text { Died } 2 \text { months after } \\
\text { diagnosis }\end{array}$ \\
\hline $\begin{array}{l}\text { Lohmann } \\
\text { et al. [10] }\end{array}$ & $58 /$ female & Dysphagia & $\begin{array}{l}\text { Polypoid and ul- } \\
\text { cerated tumor }\end{array}$ & $\begin{array}{l}\text { Distal } \\
\text { esophagus }\end{array}$ & $11 \mathrm{~cm}$ & Surgery & $\begin{array}{l}\text { Died } 4 \text { months after } \\
\text { diagnosis }\end{array}$ \\
\hline $\begin{array}{l}\text { Suzuki } \\
\text { et al. [10] }\end{array}$ & 58/male & No symptom & Ulcerated tumor & $\begin{array}{l}\text { Middle } \\
\text { esophagus }\end{array}$ & $6.5 \mathrm{~cm}$ & $\begin{array}{l}\text { Surgery, CT, } \\
\text { IT and ET }\end{array}$ & $\begin{array}{l}\text { Alive } 53 \text { months } \\
\text { after surgery (recur- } \\
\text { rence at } 11 \text { months) }\end{array}$ \\
\hline $\begin{array}{l}\text { Heidemann } \\
\text { et al. [10] }\end{array}$ & 75/male & $\begin{array}{l}\text { Dysphagia weight } \\
\text { loss }\end{array}$ & Ulcerated tumor & $\begin{array}{l}\text { Middle } \\
\text { and distal } \\
\text { esophagus }\end{array}$ & $8 \mathrm{~cm}$ & Surgery & $\begin{array}{l}\text { n.a. } \\
\text { recurrence at } \\
7 \text { months }\end{array}$ \\
\hline $\begin{array}{l}\text { De Simone } \\
\text { et al. [10] }\end{array}$ & 58/female & $\begin{array}{l}\text { Dysphagia, retro- } \\
\text { sternal pain, } \\
\text { weight loss }\end{array}$ & Polypoid tumor & $\begin{array}{l}\text { Middle } \\
\text { esophagus }\end{array}$ & $3 \mathrm{~cm}$ & Surgery & $\begin{array}{l}\text { Died } 16 \text { months } \\
\text { after surgery }\end{array}$ \\
\hline $\begin{array}{l}\text { Stringa } \\
\text { et al. }{ }^{1} \text { [2] }\end{array}$ & 59/male & $\begin{array}{l}\text { Mild dysphagia, } \\
\text { heartburn, moder- } \\
\text { ate anorexia, } \\
\text { weight loss }\end{array}$ & $\begin{array}{l}\text { Polypoid and ul- } \\
\text { cerated tumor }\end{array}$ & $\begin{array}{l}\text { Lower } \\
\text { third of the } \\
\text { esophagus }\end{array}$ & $8 \mathrm{~cm}$ & $\begin{array}{l}\text { Surgery and } \\
\text { CT }\end{array}$ & $\begin{array}{l}\text { n.a. } \\
\text { Disseminated } \\
14 \text { months after } \\
\text { diagnosis }\end{array}$ \\
\hline Terada [10] & $87 /$ female & Nausea, vomiting & Ulcerated tumor & $\begin{array}{l}\text { Distal } \\
\text { esophagus }\end{array}$ & n.a. & $\mathrm{CT}$ and $\mathrm{RT}$ & $\begin{array}{l}\text { Died } 12 \text { months after } \\
\text { first presentation }\end{array}$ \\
\hline Terada [10] & $56 /$ male & Dysphagia & Polypoid tumor & $\begin{array}{l}\text { Middle } \\
\text { esophagus }\end{array}$ & n.a. & CT and RT & $\begin{array}{l}\text { Died } 7 \text { months after } \\
\text { first presentation }\end{array}$ \\
\hline $\begin{array}{l}\text { Kranzfelder } \\
\text { et al. [3] }\end{array}$ & 57/male & $\begin{array}{l}\text { Dysphagia, dyno- } \\
\text { phagia, weight loss }\end{array}$ & Ulcerated tumor & $\begin{array}{l}\text { Distal } \\
\text { esophagus }\end{array}$ & $7 \mathrm{~cm}$ & $\begin{array}{l}\text { Surgery and } \\
\text { RT }\end{array}$ & $\begin{array}{l}\text { Died } 4 \text { months after } \\
\text { diagnosis }\end{array}$ \\
\hline $\begin{array}{l}\text { Ramaswamy } \\
\text { et al. [4] }\end{array}$ & 24/female & $\begin{array}{l}\text { Dysphagia neck } \\
\text { swelling }\end{array}$ & Polypoid tumor & $\begin{array}{l}\text { Cervical } \\
\text { esophagus }\end{array}$ & $4.3 \mathrm{~cm}$ & $\begin{array}{l}\text { Surgery and } \\
\text { CT }\end{array}$ & $\begin{array}{l}\text { Died } 8 \text { months after } \\
\text { first presentation }\end{array}$ \\
\hline Current case & 77/female & Dysphagia & Polypoid tumor & $\begin{array}{l}\text { Middle } \\
\text { esophagus }\end{array}$ & $2 \mathrm{~cm}$ & Surgery & $\begin{array}{l}\text { Alive } 60 \text { months after } \\
\text { first presentation }\end{array}$ \\
\hline
\end{tabular}

with prominent nucleoli. Melanin pigment could hardly be seen except in a few tumor cells and in some macrophages located in the periphery of the tumor. Many tumor cells also showed strongly positive immunohistochemical reactivity for S-100 protein, MELAN-A, and HMB45, but were negative for CD34, DOG1, and actin ( $\triangleright$ Fig.3). In addition, we retrospectively found small black spots beside the main tumor on EGD ( $\triangleright$ Fig. 1), and thus this lesion was diagnosed as MME.

Based on these findings and the definition of AMME as described by Taniyama et al. [1], the diagnosis of PAMME was confirmed. Three years after surgery, the patient is stable. Follow- up computed tomography scan performed every 6 months after surgery has shown no signs of recurrence to date.

This case report indicates the possibility of achieving excellent outcomes with no recurrence 3 years after surgery and diagnosis of AMME and 5 years after initial detection. 


\section{Discussion}

The present case raises 2 significant points. First, the diagnosis of AMME is sometimes difficult. Second, the prognosis of patients with MME is very poor, but in some patients the prognosis is good.

SCC is the most common tumor of the esophagus, accounting for $95.5 \%$ of all primary tumors of the esophagus in Japan [1]. Nonepithelial malignant tumors of the esophagus occur at a frequency of only $0.5 \%$, with carcinosarcoma being found most frequently, followed by MME [1]. AMME produces little or no melanin, and comprises approximately $10 \%$ to $25 \%$ of all MME [2-4].

The diagnosis of AMME on preoperative biopsy is often difficult, but the diagnosis of MME is relatively easier because of characteristic pigmentation, which is pathognomonic of the condition. Biopsy specimens of AMME may be misdiagnosed as poorly differentiated SCC. Taniyama et al. reported 10 cases of AMME misdiagnosed as undifferentiated carcinoma, SCC, and leiomyosarcoma by biopsy specimens from 1954 to 1987 [1]. In our patient, the diagnosis of AMME was actually made 2 years after the first presentation.

Generally, the prognosis of MME is very poor, with a 5-year survival of $2.2 \%$ and median survival of approximately 10 months [5]. Despite the poor prognosis, the treatment policy in patients with MME is wide surgical resection and dissection of the lymph nodes. However, some authors have reported the remarkable efficacy of neoadjuvant chemotherapy on MME, and other authors have described the effectiveness of postoperative adjuvant chemotherapy in patients with lymph node metastases [6,7]. Furthermore, Miyatani et al. reported the successful resection of a small lesion of MME by endoscopic mucosal resection [8]. These facts could occasionally contribute to difficulty in deciding on a treatment plan.

In the current case, the patient achieved excellent outcomes with no recurrence 3 years after surgery and 5 years after initial detection of the tumor. AMME is an extremely rare lesion, and our search of the PubMed database yielded only 14 cases in 9 reports accumulated over a 20-year period from 1996 to 2015 ( $\triangleright$ Table 1) $[9,10]$. These reports state the mean survival of AMME as approximately 9 months. Therefore, our case of slowgrowing AMME with long survival is extremely rare. Still, little is known about the natural history of non-aggressive esophageal tumors and whether they should be treated. According to the accumulated reports ( $\downarrow$ Table 1 ), there was no significant difference between non-aggressive and aggressive AMME in terms of age, sex, location, size, and endoscopic findings.

Few reports have discussed the slow-growing type of MME and so it is difficult to predict the malignant behavior of this case. It may be improbable that a small low-grade malignant tumor without blood and lymph vessel invasion could metastasize to lymph nodes and other organs. Nevertheless, it is also necessary to evaluate other cases in order to determine whether this type of non-aggressive slow-growing melanoma transforms into the common, aggressive type of MME.

\section{Conclusion}

In conclusion, the current case and review of the literature suggest that our case of slow-growing AMME with long survival is extremely rare. Evaluation of more cases is required; however, it is important to further assess and characterize MME.

\section{Competing interests}

None

References

[1] Taniyama K, Suzuki H, Sakuramachi S et al. Amelanotic malignant melanoma of the esophagus: case report and review of the literature. Jpn J Clin Oncol 1990; 20: 286 - 295

[2] Stringa O, Valdez R, Beguerie JR et al. Primary amelanotic melanoma of the esophagus. Int J Dermatol 2006; 45: 1207 - 1210 Review

[3] Kranzfelder M, Seidl S, Dobritz M et al. Amelanotic esophageal malignant melanoma: case report and short review of the literature. Case Rep Gastroenterol 2008; 2: 224-231

[4] Ramaswamy B, Bhandarkar AM, Venkitachalam S et al. Amelanotic malignant melanoma of the cervical oesophagus. BMJ Case Rep 2014: 2014

[5] Naomoto Y, Perdomo JA, Kamikawa Y et al. Primary malignant melanoma of the esophagus: report of a case successfully treated with pre- and post-operative adjuvant hormone-chemotherapy. Jpn J Clin Oncol 1998; 28: $758-761$

[6] Yano M, Shiozaki H, Murata A et al. Primary malignant melanoma of the esophagus associated with adenocarcinoma of the lung. Surg Today 1998; 28: $405-408$

[7] Kato N, Kamino K, Yamashita T et al. Primary malignant melanoma of the esophagus. Gan No Rinsho 1986; 32: 1459-1465

[8] Miyatani H, Yoshida Y, Ushimaru S et al. Slow growing flat-type primary malignant melanoma of the esophagus treated with cap-assisted EMR. Dig Endosc 2009; 21: 255 - 257

[9] Carr-Locke DL, Mehra K, Kumar S et al. Primary amelanotic malignant melanoma of the esophagus. New York: Medscape LLC; 2009: Available from: http://www.medscape.com/viewarticle/712478

[10] Bisceglia M, Perri F, Tucci A et al. Primary malignant melanoma of the esophagus: a clinicopathologic study of a case with comprehensive literature review. Adv Anat Pathol 2011; 18: 235-252 